\title{
THE CHARACTERISTICS OF HOSPITALIZED MEASLES AFFECTED CHILDREN DURING THE 2017-2018 EPIDEMIC IN THE JABLANICA DISTRICT
}

\author{
Marija Stojiljković1,2, Ivan Rančić2, Milan Golubović2,3, Milica Jakovljevićz,3, \\ Mirjana Miljković ${ }^{1}$
}

\begin{abstract}
Despite the availability of safe, effective and inexpensive vaccine since the 1960s, in 2018, more than 140.000 people worldwide died from measles. The aim of this study was to determine socio-epidemiological and clinical characteristics among hospitalized, measlesinfected children during the epidemic from December 2017 to July 2018 in the Jablanica District and to estimate the influence of socio-epidemiological factors on the severity of disease. This cross-sectional study involved 55 measles-infected, hospitalized children at the Pediatric Department of the General Hospital of Leskovac. Data were collected with an original questionnaire and analyzed using descriptive statistics methods. The influence of factors on the severity of disease among infected children with and without complications was examined using $\chi^{2}$ and t-test. $\mathrm{P}<0.05$ was considered statistically significant.

During the measles epidemic in the Jablanica District in 2017-2018, 110 children were affected, aged 0-19 years. Out of a total measles affected children in the Jablanica District only $9(8.18 \%)$ were vaccinated, of which $5(4.54 \%)$ were hospitalized. A total of 55 measlesinfected, hospitalized children aged $22.85 \pm 23.94$ months were analyzed. The most infected children, 25 (45.45\%), were aged 0-12 months. The infected children were mostly living in poor conditions, 34 (61.81\%). Pneumonia was the most common complication, 24 (51.88\%). There were no lethal outcomes. Severe complications were more frequent in younger children $(p<0.05)$, in children who lived in poor conditions $(p<0.05)$ and in those who had infection during the winter $(p<0.05)$.

The development and implementation of strategies to achieve high coverage for measles vaccination and revaccination are necessary for measles elimination.
\end{abstract} Acta Medica Medianae 2020;59(2):53-59. children

Key words: measles, epidemic, socio-epidemiological factors, complications,

\footnotetext{
${ }^{1}$ Pediatric Department, General Hospital in Leskovac, Leskovac, Serbia

${ }^{2}$ University of Niš, Faculty of Medicine, Niš, Serbia

${ }^{3}$ Pediatric Internal Diseases Clinic, Clinical Centre of Niš, Niš, Serbia
}

Contact: Marija Stojiljković,

Janka Veselinovića 13, 16000 Leskovac, Serbia

E-mail: marijastojiljkovic986@gmail.com

\section{Introduction}

Measles is a highly contagious, infective and preventable disease. Despite the availability of safe, effective and inexpensive vaccine since the 1960s, in 2018, more than 140.000 people died from measles in the world (1). European Region achieved its highest ever estimated coverage for the second dose of measles vaccination in 2017 (90\%). Nevertheless, there were countries with measles outbreaks which have experienced a range of challenges in recent years including:

a) a decline or stagnation in overall routine immunization coverage in some cases,

b) sub-optimal coverage at sub-national level or among some marginalized groups and

c) immunity gaps in older populations.

Most cases of infection are occurring in unvaccinated or incompletely vaccinated individuals (2). In the WHO European Region during 2017, 25.863 measles cases were reported, while in 2018, 82.596 measles cases were reported. (3).

From 2017 to 2019, the measles epidemic outbreak happened in Serbia with 5.798 measles cases and 15 measles related deaths (4). Those were the first deaths caused by measles in Serbia after 20 years. The most cases of measles affected 
were recorded in the Belgrade City, Nišava, Pčinja, Raška and the Jablanica Districts (4).

Symptoms of measles usually develop 7-10 days after exposure to infected person. Initially symptoms are fever $\left(>38^{\circ} \mathrm{C}\right)$, cough, coryzal symptoms, conjunctivitis and Koplik's spots. After three to five days, maculopapular rash starts usually on the face and spreads to the rest of the body $(5,6)$. Common complications include pneumonia, croup, diarrhea, otitis media, conjunctivitis, mouth ulcers, and uncommon complications include encephalitis, myocarditis, pneumothorax, appendicitis. Long term measles complications are blindness, subacute sclerosing panencephalitis, chronic lung disease, malnutrition, growth impairment and recurrent infections $(5,7)$. Although measles infection is preventable, it can be a fatal and life-threatening infection.

\section{The aim}

The aim of this study was to determine clinical and socio-epidemiological characteristics among measles infected, hospitalized children during epidemic from October 2017 to July 2018 in the Jablanica District, and to estimate the influence of socioepidemiological factors on the severity of the disease.

\section{Methods and patients}

This cross-sectional study involved 55 measles affected children hospitalized in the Pediatric Department of General Hospital in Leskovac during the outbreak of measles in the Jablanica District, from October 2017 to July 2018. The criteria for hospitalization were the presence of serious complications and parental/guardian consent for hospital treatment. Children with measles without complications who were living in poor socio-economic and hygiene conditions without the possibility of isolation and adequate care were also treated at the hospital. Prior to admission to the Pediatric Department, case history was taken and clinical examination was performed. Parents were additionally asked about socio-economic status, living conditions, contact with infected person, affected members in the family, vaccination status of the child and reasons for nonvaccination. Immunization card was requested. In cases of confirmed contact with the measles affected and with typical clinical manifestation (generalized maculopapular rash, fever above $38^{\circ} \mathrm{C}$, cough, coryzal syndrome and conjunctivitis), the case was diagnosed as measles. In cases where there was no information about contact with the measles affected, but with typical clinical measles manifestation, serological confirmation was performed. It was performed at the Institute of Virology, Vaccines and Sera "Torlak" in Belgrade. Detection of specific IgM antibodies in serum confirmed the diagnosis of measles.

Measles complications were established using anamnestic data and physical examination (diarrhea, laryngitis, bronchitis, purulent conjunctivitis and stomatitis). Otitis media was confirmed by an otoscopic exam. Pneumonia was confirmed by a chest radiograph with the presence of a pulmonary infiltrate. Central nervous system was considered to be affected if there was lethargy, irritability, headache, febrile seizures, disorientation or other neurological deficits.

According to the WHO Child Growth Standards (8), weight-for-age was classified as malnourished, well nourished, overweight and obese.

Data were collected with an original questionnaire that was specially created for this research and analyzed using descriptive statistics methods: frequency, percentage, means \pm standard deviation, depending on the type and variable distribution. Influence of social and epidemic factors on the severity of disease among the affected children with and without complications was examined using $\chi^{2}$ and t-test for categorical and continuous dependent variables, respectively. A value of $p<0.05$ was considered statistically significant.

\section{Results}

During the measles epidemic in the Jablanica District 2017-2018, 110 children were affected, age between 0-19 years. Eighty-nine (80.9\%) affected children were referred to the Pediatric Department of General Hospital in Leskovac. Fifty-five (50\%) children were hospitalized. In $11(10 \%)$ measles affected children hospitalization was indicated due to complications, but the parents refused the hospital treatment. Out of a total measles affected children in the Jablanica District only $9(8.18 \%)$ were vaccinated, of which $5(4.54 \%)$ were hospitalized.

A total of 55 measles affected, hospitalized children aged $22.85 \pm 23.94$ months were analyzed. The most affected children were between $0-12$ months $(45.45 \%)$. Nearly one-quarter of the children $(23.63 \%)$ were malnourished. There were $90.9 \%$ unvaccinated children. Reasons for non-vaccination were children under one year of age, 25 $(45.45 \%)$, delayed routine immunization, 7 $(12.72 \%)$, insufficient health education of parents about the vaccination and measles prevention, 16 (29.09\%), migration/divorce of parents, 2 (3.63\%). Most of the affected children lived in poor living conditions $(61.81 \%)$, in multi-member families with some members also infected (54.54\%). Infection was common in winter months $(65.45 \%)$ (Table 1$)$.

In the clinical presentation, typical signs (fever, cough, coryzal symptoms, conjunctivitis and maculopapular rash) were present in almost all infected children. Complications occurred in $78.1 \%$ of infected, hospitalized children. The most frequent complications were respiratory $(55.81 \%$ pneumonia, $20.93 \%$ croup and $20.93 \%$ bronchitis). Diarrhea was present in $34.83 \%$ of cases. No encephalitis was present. Only one case of febrile convulsions was reported. There was no lethal outcome. Treatment outcome was favorable for all children (Table 2). 
Table 1. Demographic, socio-epidemiological characteristics and outcome of treatment in hospitalized, measles affected children

\begin{tabular}{|c|c|}
\hline Variable & Value \\
\hline Total number of hospitalized children, n (\%) & $55(100 \%)$ \\
\hline Males/females, n (\%) & $27 / 28(49.1 / 50.9)$ \\
\hline Age (months), $X \pm S D$ & $22.85 \pm 23.94$ \\
\hline \multicolumn{2}{|l|}{ Age categories (months), n (\%) } \\
\hline $0-12$ & $25(45.45 \%)$ \\
\hline $13-24$ & $15(27.27 \%)$ \\
\hline $25-48$ & $8(14.54 \%)$ \\
\hline$>48$ & $7(12.72 \%)$ \\
\hline Roma children, $\mathrm{n}(\%)$ & $43(78.1 \%)$ \\
\hline $\mathrm{BMI}-\mathrm{SD}, \mathrm{X} \pm \mathrm{SD}$ & $-0.603 \pm 1.62$ \\
\hline \multicolumn{2}{|l|}{ BMI-SD, WHO categories, n (\%) } \\
\hline malnourished & $13(23.63 \%)$ \\
\hline normal & $41(74.54 \%)$ \\
\hline overweight & $1(1.81 \%)$ \\
\hline \multicolumn{2}{|l|}{ Vaccine status, n (\%) } \\
\hline unvaccinated & $50(90.90 \%)$ \\
\hline vaccinated & $5(9.09 \%)$ \\
\hline \multicolumn{2}{|l|}{ Reasons for non-vaccination, n (\%) } \\
\hline children under 1 year & $25(45.45 \%)$ \\
\hline delayed routine immunization & $7(12.72 \%)$ \\
\hline insufficient health education of parents & $16(29.09 \%)$ \\
\hline migration/divorce of parents & $2(3.63 \%)$ \\
\hline Poor living conditions, n (\%) & $34(61.81 \%)$ \\
\hline Infected during winter months, $\mathrm{n}(\%)$ & $36(65.45 \%)$ \\
\hline Affected member of family, $\mathrm{n}(\%)$ & $30(54.54 \%)$ \\
\hline
\end{tabular}

BMI - body mass index; WHO - World Health Organization; X- mean value; SD - standard deviation

Table 2. Clinical manifestation, complications and outcome of treatment in measles affected, hospitalized children

\begin{tabular}{|c|c|}
\hline Variable & Value \\
\hline 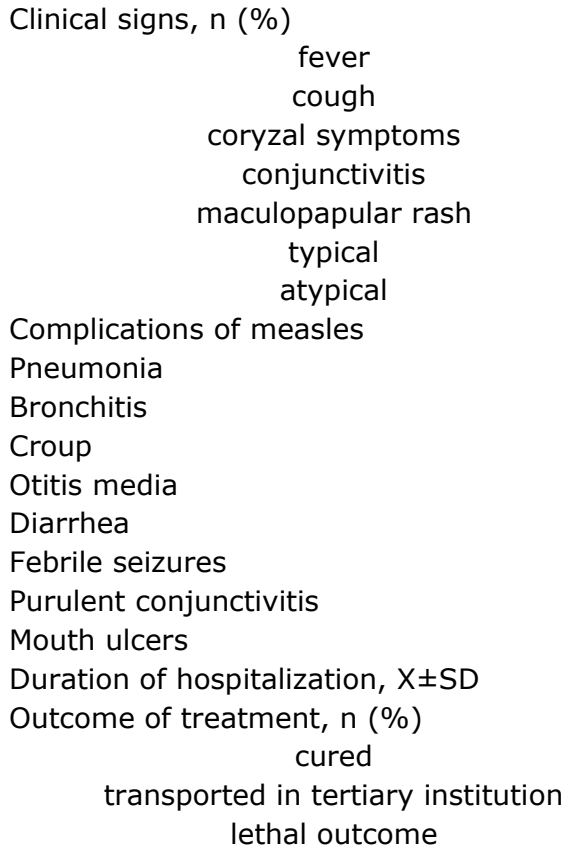 & $\begin{array}{c}55(100 \%) \\
51(92.72 \%) \\
55(100 \%) \\
54(96.36 \%) \\
55(100 \%) \\
47(85.45 \%) \\
8(14.54 \%) \\
43(78.1 \%) \\
24(55.81 \%) \\
9(20.93 \%) \\
9(20.93 \%) \\
1(2.32 \%) \\
15(34.83 \%) \\
1(2.32 \%) \\
22(51.16 \%) \\
9(20.93 \%) \\
5.65 \pm 2.67 \\
54(98.18 \%) \\
1(1.81 \%) \\
0(0.0 \%)\end{array}$ \\
\hline
\end{tabular}

X- mean value; SD - standard deviation 
Young age $(19.93 \pm 19.31$ vs. $33.33 \pm 35.18)$, poor living conditions $(74.41 \%$ vs. $33.3 \%)$ and infection during winter months $(74.41 \%$ vs.33.3\%) were statistically significant $(p<0.05)$ in children with measles with complications. In both groups, there were more than half $(58.33 \%$ vs. $53.48 \%)$ infected family members $(p>0.05)$. Gender structure, nourishment $(-0.67 \pm 1.66$ vs. $0.33 \pm 1.50)$, vaccina- tion status ( $16.66 \%$ vs. $6.9 \%)$, duration of fever $(6.48 \pm 2.27$ vs. $6.25 \pm 2.05)$ and duration of rash $(6.5 \pm 1.67$ vs. $7.23 \pm 1.81)$ were not significantly different between children with complications and without complications $(p>0.05)$. Complications significantly extended the duration of hospitalization $(3 \pm 1.12$ vs. $6.39 \pm 2.50)(p<0.05)($ Table 3$)$.

Table 3. Characteristics of measles affected children with and without complications

\begin{tabular}{|c|c|c|c|}
\hline Variable & $\begin{array}{l}\text { Without complications } \\
n=12\end{array}$ & $\begin{array}{l}\text { With complications } \\
n=43\end{array}$ & p-value \\
\hline Males, n (\%) & $6(50 \%)$ & $21(48.83 \%)$ & NS \\
\hline Age (months), $X \pm S D$ & $33.33 \pm 35.18$ & $19.93 \pm 19.31$ & $<0.05$ \\
\hline BMI-SD, $X \pm S D$ & $-0.67 \pm 1.66$ & $-0.33 \pm 1.50$ & NS \\
\hline Vaccinated, n (\%) & $2(16.66 \%)$ & $3(6.97 \%)$ & NS \\
\hline Poor living conditions, $\mathrm{n}(\%)$ & $4(33.3 \%)$ & $32(74.41 \%)$ & $<0.05$ \\
\hline Affected member of family, $\mathrm{n}(\%)$ & $7(58.33 \%)$ & $23(53.48 \%)$ & NS \\
\hline Infected during the winter months & $4(33.3 \%)$ & $32(74.41 \%)$ & $<0.05$ \\
\hline Duration of fever, $X \pm S D$ & $6.48 \pm 2.27$ & $6.25 \pm 2.05$ & NS \\
\hline Duration of rash, $\mathrm{X} \pm \mathrm{SD}$ & $6.5 \pm 1.67$ & $7.23 \pm 1.81$ & NS \\
\hline Duration of hospitalization, $\mathrm{X} \pm \mathrm{SD}$ & $3 \pm 1.12$ & $6.39 \pm 2.50$ & $<0.05$ \\
\hline
\end{tabular}

BMI - body mass index; $X$ - mean value; SD - standard deviation

\section{Discussion}

In this cross sectional study we analyzed demographic, socio-epidemiological and clinical characteristics in all measles affected, hospitalized children and compared them among children with measles with and without complications. A similar outbreak of measles occurred in 2011 in Leskovac, which started in the Roma community and spread to the general population (10). An average age of measles affected in Europe, during the measles outbreak in 2017 and 2018 has progressively increased, from 10 years in 2009 to 17 years in 2019. In the period of 2016-2019, the average annual rates were highest in infants, up to 44 times higher than in the other age groups. Almost half (45\%) of all measles deaths were reported in infants (11). Most measles-related deaths are caused by complications associated with the disease. Serious complications are more common in children under the age of 5 , or adults over the age of 30 (12). Unvaccinated young children are at the highest risk of measles and its complications, including death. In Serbia, the most affected age groups were under 5 years and over 30 years, that are the groups with the highest risk for developing complications (4). The most hospitalized, affected children were aged between $0-12$ months (45.45\%). There were $50(91 \%)$ under 5 years of age. During the measles outbreak in 2011 in Leskovac, mean age of hospitalized, infected children in our Department was 11.5 months (2-17 months) (13). This data showed that the children under 5 years of age, particularly infants, were the vulnerable groups with the high risk for measles complications in epidemics in the Jablanica District. Also, the age of affected children was increased which means that the number of vaccinated children at 12 months was decreased.

MMR vaccine is absolutely safe, effective and inexpensive vaccine which protects $90 \%$ of the recipients. Children should get two doses of MMR vaccine, starting with the first dose at 12 months of age, and the second dose at 7 years. In the Jablanica District there were $91.82 \%$ measles affected unvaccinated children. In the European Region during the measles outbreak of $2017-2018,87 \%$ of measles affected were unvaccinated (14), and in Serbia $94 \%$ of measles affected were unvaccinated (4). Coverage of the MMR vaccine in Serbia during 2018 was below $95 \%$ in $50 \%$ of the regions. The lowest coverage of revaccination was recorded in the Jablanica District $(84.4 \%)$, which can be a major cause for the periodical outbreaks of the measles in the Jablanica District (15). Only $5(4.54 \%)$ vaccinated children were hospitalized with moderate, not severe complications. Insufficient health education of parents about preventive measures and vaccination was the major reason for non-vaccination among measles affected hospitalized children (29.09\%) in this research. Anti-vaccine campaign contributes to the low MMR vaccine coverage, and it is identified by the World Health Organization as one of the top ten global health threats in 2019 (16).

Measles can be a deadly disease if it comes to developing complications. Risk factors for a severe, complicated form of measles are the young age (particularly under 1 year), malnutrition, non-vaccination, living in poor conditions, immunodeficiency (malignancy, HIV, immunosuppressive therapy), vitamin A deficiency $(5,6,17,18,19)$.

Living in socially and culturally separate communities, in overcrowded and poor conditions, with a 
close contact between the members, especially during winter months is a risk factor for the severe measles form $(6,20)$. This phenomenon is most likely the result of the intense and longer exposure to the virus, which occurs in winter months. The household characteristics (socioeconomic, sociocultural and culture of health) are in interaction with other factors (e.g. malnutrition, hypoproteinemia, vitamin $A$ and $D$ deficiency, nonimmunized children) which can increase risk for measles complications.

Almost all measles affected children had typical clinical manifestation with fever $(100 \%)$, cough $(92.72 \%)$, coryzal symptoms $(100 \%)$, conjunctivitis $(96.36 \%)$ and maculopapular rash $(100 \%)$. The most common complications were respiratory (pneumonia $55.81 \%$, bronchitis $20.93 \%$ and croup $20.93 \%$ ) and diarrhea (34.83\%). Pneumonia is the most common, serious complication of measles, which occurs in 16-77\% of hospitalized children (21, 22). In all measles-associated deaths, pneumonia is the cause of $60 \%$ (23). In the measles epidemic that occurred in Serbia during 2017-2018, 383 cases developed neurological or pulmonary complications. Nine people died of pulmonary measles complications, including two children aged four and two (14). Diarrhea with dehydration is the second common complication, most frequently among measles affected in Asia $(21,24)$. Encephalitis is a very dangerous complication with a high mortality rate. In some studies, the incidence of encephalitis was $7.8 \%$ (22). The mortality rate is $10-15 \%$ and $25 \%$ of patients had permanent neurological sequelae (25). In comparison to other studies which included measles affected children, this study showed similar occurrence for pneumonia, and low occurrence for otitis media, febrile seizures and encephalitis $(21,22,23$, $24,25)$. In the literature data, mortality is significantly associated with infancy, unvaccinated status and encephalitis (22). In this study, there were no lethal outcomes. Complications significantly extended the duration of hospitalization. Measles is a disease that can be prevented with inexpensive vaccine. Medical treatment and treatment of complications are more expensive than prevention (26). Measles infection has an adverse effect on the quality of life in affected children. Absence from school and a loss of income for parents who stay at home to care for them are a negative consequence of the infection (27). Isolation of measles affected children in hospitals, exposure of medical professionals to infection and intrahospital infection control were also problems in our Pediatric Department.

\section{Conclusion}

The result showed that the affected children were younger, unvaccinated, infected during the winter, living in poor conditions, with family members also affected, and with typical clinical presentation and complications. Severe complications were more frequent in younger children, in children who lived in poor conditions and who had an infection during the winter. Pneumonia was the most common complication. There were no lethal outcomes. Complications significantly extended the duration of hospitalization. Immunization is the only effective preventive measure against acquiring measles. Therefore, it is necessary to strengthen the immunization programs, in every district of the country, to ensure $\geq 95 \%$ 2-dose MMR coverage. Vaccination delay should be minimized in children. For susceptible adults, it is necessary to provide additional measles vaccination. Educational campaigns for the improvement of acceptance and timely vaccination with MMR vaccine among doctors and the general population are crucial. 


\section{References}

1. References ReferencesWorld Health Organization. Measles. [Internet]. [updated 2020 Jan]. Available from:

http://www.who.int/imunization/diseases/measles/en /. ;1:1205-10. [CrossRef]

2. World Health Organization. Measles-European Region. [Internet]. [updated 2019 Sept]. Available from: https://www.who.int/csr/don/06-may-2019-measleseuro/en/ [CrossRef]

3. Muscat M, Mamou MB, Singh S, de Kat C, Jankovic D, Huseynov $S$, et al. Elimination of measles in the WHO European Region-challenges persist. Bundesgesundheitsbl 2019;62(4):440-9. [CrossRef] [PubMed]

4. Institute of Public Health of Serbia. The current epidemiological situation of measles in the Republic of Serbia [internet]. 2018 [cited 2018 Mar. 13]. Available from:

http://www.batut.org.rs/index.php?content=1629.

5. World Health Organization. Treating measles in children. Geneva, 2004. [CrossRef]

6. Perry RT, Halsey NA. The clinical significance of measles: a review. The Journal of infectious diseases 2004;189 (Supplement 1):S4-16. [CrossRef] [PubMed]

7. Paules CI, Marston HD, Fauci AS. Measles in 2019 Going Backward. N Engl J Med 2019;380(23):2185-7. [CrossRef] [PubMed]

8. World Health Organization. The WHO Child Growth Standards. [Internet]. [updated 2019 Oct]. Available from:

http://www.who.int/childgrwth/sanards/en/[CrossRef]

9. Zavod za javno zdravlje Leskovac. Informacija o epidemijama malih boginja na teritoriji opštine Bojnik, Vlasotince, Grada Leskovca i fabrici Jeansi Serbia doo Leskovac na dan 20.07.2018. Godine. [Internet]. [updated 2019 Sept]. Available from: http://www.zzjzle.org.rs/epidemija-malihboginja/informacija-o-epidemijama-malih-boginja-nateritoriji-opstine-bojnik-vlasotince-grada-leskovca-ifabrici-jeansi-serbia-doo-leskovac-na-dan-20-7-2018god/_[CrossRef]

10. Institut za javno zdravlje Srbije "Dr Milan Jovanović Batut". Komunikacioni Centar. Izveštaj o zaraznim bolestima koje mogu predstavljati potencijalnu pretnju po javno zdravlje, Beograd, 2012.

11. European Centre for Disease Prevention and Control. ECDC: Insufficient vaccination coverage in EU/EEA fuels continued measles circulation. [Internet]. [updated 2019 Oct]. Available from: https://www.ecdc.europa.eu/en/news-events/ecdcinsufficient-vaccination-coverage-eueea-fuelscontinued-measles-circulation_[CrossRef]

12. World Health Organization. Measles. [Internet]. [updated 2019 Oct]. Available from: https://www.who.int/news-room/fact-sheets/detail/ measles_[CrossRef]

13. Krstić S, Miljković M, Janković I. Kliničke karakteristike malih boginja kod dece lečene u službi za pedijatriju opšte bolnice Leskovac. Apollinem medicum et asesculapium 2012;10(4):9-12.

14. European Centre for Disease Prevention and Control. Risk of measles transmission in the EU/EEA.

Stockholm, 2018. [CrossRef]

15. Institut za javno zdravlje Srbije "Dr Milan Jovanović Batut". Izveštaj o sprovedenoj imunizaciji na teritoriju Republike Srbije u 2018. Beograd, 2019.

16. World Health Organization. Ten threats to global health in 2019. [Internet]. [updated 2020 January]. Available from:

http://www.who.int/emergencies/ten-threats-toglobal-health-in-2019_[CrossRef]

17. Ismail AS, Aden MA, Abdikarim AA, Yusuf AA. Risk Factors for Measles Outbreak: An Unmatched Case Control Study in Kabridahar District, Somali Regional State, Ethiopia. American Journal of Epidemiology and Infectious Disease 2019;7(1):1-5. [CrossRef]

18. Hungerford D, Cleary P, Ghebrehewet S, Keenan A, Vivancos R. Risk factors for transmission of measles during an outbreak: matched case-control study. Journal of Hospital Infection 2014;86(2):138-43. [CrossRef] [PubMed]

19. Kouadio IK, Kamigaki T, Oshitani H. Measles outbreaks in displaced populations: a review of transmission, morbidity and mortality associated factors. BMC international health and human rights 2010; 10(1):5. [CrossRef] [PubMed]

20. Samsi TK, Ruspandji T, Susanto I, Gunawan K. Risk factors for severe measles. Southeast Asian J Trop Med Public Health 1992;23(3):497-503.

[CrossRef] [PubMed]

21. Aurangzeb B, Nisar YB, Hazir T, Burki F, Hassan M. Clinical outcome in children hospitalized with complicated measles. J Coll Physicians Surg Pak 2005; 15(9):547-51. [CrossRef] [PubMed]

22. Khan HI, Ahmad TJ. Risk factors for increased mortality in children with complications of measles. J Coll Physicians Surg Pak 1999;9:247-250.

23. Dardis MR. A review of measles. J Sch Nurs 2012; 28(1):9-12. [CrossRef] [PubMed]

24. Pongrithsukda V, Phonboon K, Manunpichu K. Measles-associated diarrhoea in northeastern Thailand. The Southeast Asian Journal of Tropical Medicine and Public Health 1986;17(1):43-47. [CrossRef] [PubMed]

25. Buchanan R, Bonthius DJ. Measles virus and associated central nervous system sequelae. Semin Pediatr Neurol 2012;19(3):107-14. [CrossRef] [PubMed]

26. Suijkerbuijk AW, Woudenberg T, Hahné SJ, Lochlainn $\mathrm{LN}$, de Melker $\mathrm{HE}$, Ruijs WL, Lugnér AK. Economic costs of measles outbreak in the Netherlands, 20132014. Emerging infectious diseases 2015;21(11): 2067-9. [CrossRef] [PubMed]

27. Ghebrehewet S, Thorrington D, Farmer S, Kearney J, Blissett D, McLeod H, Keenan A. The economic cost of measles: healthcare, public health and societal costs of the 2012-13 outbreak in Merseyside, UK. Vaccine 2016;34(15):1823-31. [CrossRef] [PubMed] 


\title{
KARAKTERISTIKE HOSPITALIZOVANE DECE OBOLELE OD MALIH BOGINJA TOKOM EPIDEMIJE OD 2017. DO 2018. GODINE U JABLANIČKOM OKRUGU
}

\author{
Marija Stojiljković1,2, Ivan Rančić2, Milan Golubović2,3, Milica Jakovljević2,3, \\ Mirjana Miljković ${ }^{1}$
}

1Pedijatrijsko odeljenje Opšte bolnice u Leskovcu, Leskovac, Srbija
2Univerzitet u Nišu, Medicinski fakultet, Niš, Srbija
${ }^{3}$ Pedijatrijska klinika za interne bolesti, Klinički centar Niš, Niš, Srbija

Kontakt: Marija Stojiljković

Janka Veselinovića 13, 16000 Leskovac, Srbija

E-mail: marijastojiljkovic986@gmail.com

Uprkos postojanju bezbedne, efikasne i jeftine vakcine još od 1960. godine, u 2018. godini u svetu je umrlo 140000 ljudi zbog malih boginja. Cilj ovog rada je da ispita kliničke i socio-epidemiološke karakteristike hospitalizovane dece obolele od malih boginja, tokom epidemije od 2017. do 2018. godine u Jablaničkom okrugu i da utvrdi uticaj socio-epidemioloških faktora na ozbiljnost oboljenja. Radi se o studiji preseka, kojom je obuhvaćeno 55 obolele, hospitalizovane dece na Odeljenju pedijatrije Opšte bolnice Leskovac. Podaci su prikupljani originalnim upitnikom i analizirani upotrebom deskrptivnih statističkih metoda. Uticaj ispitivanih faktora na težinu bolesti među obolelom decom, sa komplikacijama i bez njih, testiran je upotebom $\chi^{2}$ i t-testa. Statistički značajnim smatrana je vrednost $p<0,05$. Tokom epidemije malih boginja u Jablaničkom okrugu, ukupno je obolelo 110 dece, od novorođenčadi do dece uzrasta do 19 godina. Od obolelih MMR vakcinu je primilo njih 9 $(8,18 \%)$, od kojih je $5(4,54 \%)$ bilo bolnički lečeno. Ukupno je hospitalizovano 55 dece, koja su dalje analizirana. Najviše hospitalizovanih bilo je u uzrastu od novorođenčadi do dece stare 12 meseci - njih $25(45,45 \%)$. Ozbiljne komplikacije bile su češće među decom mlađom od 12 meseci $(p<0,05)$, decom koja su živela u siromašnim uslovima $(p<0,05)$ i decom koja su obolela tokom zimskih meseci $(p<0,05)$. Najčešća komplikacija bila je pneumonija - 24 slučaja $(55,81 \%)$. Nije bilo letalnih ishoda.

Razvoj i implementacija strategija za postizanje visokog ishoda lečenja, što obuhvata vakcinacije i revakcinacije MMR vakcinom, neophodni su za prevenciju i eradikaciju malih boginja.

Acta Medica Medianae 2020;59(2):53-59.

Ključne reči: male boginje, epidemija, socio-epidemiološki faktori, komplikacije,

deca

This work is licensed under a Creative Commons Attribution 4.0 International (CC BY 4.0) Licence 